Meta

Journal des traducteurs

Translators' Journal

\title{
Is Ethnocentrism an Obstacle to Finding a Comprehensive Translation Theory?
}

\section{Paul F. Bandia}

Volume 40, numéro 3, septembre 1995

La traduction, qu'est-ce à dire? Phénoménologies de la traduction

URI : https://id.erudit.org/iderudit/001966ar

DOI : https://doi.org/10.7202/001966ar

Aller au sommaire du numéro

Éditeur(s)

Les Presses de l'Université de Montréal

ISSN

0026-0452 (imprimé)

1492-1421 (numérique)

Découvrir la revue

Citer cet article

Bandia, P. F. (1995). Is Ethnocentrism an Obstacle to Finding a Comprehensive Translation Theory? Meta, 40(3), 488-496. https://doi.org/10.7202/001966ar

\section{Résumé de l'article}

La mondialisation de la communication et des échanges rend nécessaire une approche de la traduction, acte culturel, qui soit moins ethnocentrique et plus universelle, plus complète. Les débats qui opposent depuis longtemps les sourciers aux ciblistes n'ont fait qu'accentuer le penchant ethnocentrique de diverses écoles en traductologie. On remarque ainsi la faiblesse d'une approche cibliste dans la traduction entre deux univers culturels et linguistiques éloignés, dans le cas de la traduction d'une oeuvre africaine vers une langue européenne par exemple. Cet article a pour but de démontrer qu'il ne s'agit pas de favoriser l'une ou l'autre des approches, mais plutôt de trouver un compromis qui tienne compte de l'ensemble des objectifs communicatifs de l'oeuvre à traduire. 


\title{
IS ETHNOCENTRISM AN OBSTACLE TO FINDING A COMPREHENSIVE TRANSLATION THEORY?
}

Paul Bandia

Montreal conada

\begin{abstract}
Résumé
La mondialisation de la communication el des échanges rend nécessaire une approche de la traduction. acte culourel. qui soit moins ethnocentrique et plus universelle. plas complète

Le's débats qui opposent depuis longtempss les sourriers aus ciblistes n'ont fait qu'accentuer le penchant ethnocentrique de diverses écoles en traductologie'. On remarque ainsi la faiblesse d'une approche cibliste dans la traduction entre desu univers culturels et linguistiques éloignés, dans le cas de la traduction d'une a'ure africaine vers une langue européenne par exemple.

Cet article a pour but de démontrer qu'il ne s'agit pas de favoriser l'une ou l'autre des approches, mais plutôt de tronser un compromis qui tienne compte de l'ensemble des objecrifs communic atifs de l' apure à traduire.
\end{abstract}

\section{INTRODUCTION}

It is a generally accepted fact that Translation Studies (TS hereafter) is a multidisciplinary field, and this is generally viewed as one of the great attributes of the discipline. Input from various areas of scholarship have enriched and widened research in TS and the chances of actually formulating a comprehensive translation theory have never been better. Yet, sometimes, the multidisciplinary foundation of TS appears to be on shaky ground as finding a common voice in this "babelic" approach to TS is still quite elusive. There is a tendency for each school of thought 10 want to tighten its grip on TS sometimes to the exclusion (or detriment) of other views. Defining one's approach by merely seeking to destroy others will certainly not take us very far. The situation is further complicated by a strong desire for cultural (nationalistic) assertion, which is rather ironic as TS by definition deals with at least two cultural systems. Given its bi-lingual and bicultural nature, one would expect TS to be more of a "negotiating" (or cooperative) discipline rather than one in which different ethno-cultural groups try to score points. Most books dealing with scholarly research in TS today have their ethno-cultural agenda to push. Depending on where one shops, one is likely to come across various "clans" such as the Scandinavian, the French and the Anglo-Saxon, just to name a few. These "clans" often have quite obvious nationalist interests, which, understandably, might be a result of the need to pander to their respective national governments to obtain funding. It might also be an honest desire on the part of the "clans" to deal with what they are most comfortable with. and avoid venturing into an unknown territory. And all this is fine as long as one can learn a thing or two about other peoples, other cultures and other languages. However, the landscape is bound to change when it has to do with finding an empirically testable translation theory. 


\section{THE EUROCENTRIC BIAS}

Although there is generally a clear fragmentation of approaches to TS, the impact of ethnocentrism in TS is even more apparent when one observes the unequivocal Eurocentric bias of research in this area. This issue has been broached by some scholars in the field but only in a fleeting manner, often to point to the need for a global approach to TS in the light of the current globalization of world markets. TS, as carried out in the industrialized world, has yet to take the realities (or input) of the pre-industrialized world seriously.

For the most part, TS have mainly been concerned with translating between European languages. Translation involving non-Western or distant (or alien) cultures has been given relatively limited attention in the study of translation theory. For instance, only a few scholars, usually anthropologists. sociologists and linguists (e.g., von Humboldt, Malinowski, Sapir, Whorf, etc.) have shown an interest in the problems of translation regarding non-Western languages. But for a few exceptions, (e.g., Nida, Mounin), when this has happened, the main objective has not been translation theory per se; rather it has often been to enhance studies in areas such as anthropology, sociology and language philosophy. Some of these studies have served mainly to highlight the differences between the civilizations of industrialized and pre-industrialized peoples (e.g., von Humboldt, Sapir, Whorf, Levi-Strauss, etc.) often with the implied message of the superiority of the former. Although Bible translators such as Nida and Taber (1974) have dealt with non-European languages in the light of translation theory, the initial focus of their work seems to have been to seek ways of adequately conveying Judeo-Christian beliefs and doctrines to pre-industrialized societies. Therefore, translation as an intercultural communication activity involving non-Westem, or alien, language cultures has only been paid lip service so far.

\section{TRANSLATION AND THE NEW WORLD ORDER}

Today, with the movement of peoples around the world, the refinement and diffusion of instruments of mass communication and the blending of world economic and political life, the study of communication between distant or non-related cultures has gained new significance. Peoples of different linguistic and cultural backgrounds are forced to coexist and communicate with one another at a more frequent and serious level. Also, the consequences of colonialism and the direction of the world economic order have brought about a closer contact between the Third World and the industrialized nations. The "colonized" have been forced by circumstances to adopt and use the language of the "colonizer" on a regular basis for more pressing communication needs, and certain factors have resulted that are of particular interest to the sociolinguist.

During the last few decades the great metropolitan centres of the industrialized nations have been turned into the modern "Babels" of the world. with a cosmopolitan mix of peoples of various ethnic, religious, cultural and linguistic backgrounds living together side-by-side. As Snell-Hornby puts it, "In our world that is rapidly growing smaller, international communication across cultures and even between the remotest corners of the Earth is gradually taken for granted, and that includes overcoming language barriers and cultural differences" (1988: 131). Given the current state of affairs, the need for a systematic and empirical understanding of inter-cultural communication has become even more pressing. A conscious scientific elucidation of this phenomenon would help prevent communication breakdown among the peoples of the world, and would avoid negative stereotyping that may result from a lack of awareness of the culture-bound differences between peoples of different sociocultural backgrounds. 
Indeed, recent developments in the study of language as a function of society have increased the chances for a more comprehensive theory of translation. One of the avenues now being explored is that which views translation (particularly literary translation) as a cultural rather than a purely linguistic transfer. The translation process is viewed as an act of communication rather than a form of eranscoding. In this process, translation is viewed as an "integral part of the norld and not as an isolated specimen of language" (Snell-Hornby 1990: 8()-82). In loday 's world, there is an increasing need to grasp the relevance of the degree of sociocultural distance. especially in the event of communication between heterogeneous ethnolinguistic systems. This might provide the much needed shot in the arm for us to venture beyond our ethnocentric enclaves.

\section{ETHNOCENTRISM AND ITS LIMITATIONS}

The metropolitan world in which we live was brought about by a globalizing process triggered by modern imperialism, where there is an obvious interdependence of cultural terrains in which the colonizer and colonized coexist (Said 1993: xx). It is thus rather ironic that the tendency is for different groups to strive to assert their respective identity. There is indeed an ever-increasing desire for nationalism which manifests itself in an unparalleled display of separatism and nativism. Culture assumes a certain centrality as various groups battle each other through projections of their rival histories, geographies and historiographies. At some point, it becomes almost impossible to dissociate culture from the concept of nation or state; hence, culture becomes a source of identity. The downside of this is that such cultural assertions often result in a differentiation of "us" from "them," "almost always with some degree of xenophobia" (Said 1993: xiii). In this context liberal philosophies such as multiculturalism and hybridity have no place.

My main concern is the impact of this (neo-)imperialist attitude on research in TS. Translation is about bridging gaps between languages and cultures, and its importance in the cosmopolitan world cannot be overemphasized. Yet, ethnocentrism seems to have crept into the debates on translation theory, and this fact is at the core of some passionate and violent debates about the direction research in TS should take. We are all familiar with the irreconcilable and strongly held views of the "sourciers" vs, the "ciblistes." The ethnocentric biases of these opposing philosophies in TS are indeed obvious, as it is about maintaining the linguistic and cultural integrity of a linguistic community, be it the source or target language community. Indeed, there is nothing fundamentally wrong with a strong desire to preserve one's language, culture and identity, although this has become an almost insurmountable task in today's cosmopolitan world. In fact. linguistic and cultural purity has become a myth. As clearly stated by Said, "Far from being unitary or monolithic or autonomous things. cultures actually assume more 'foreign' elements, alterities, differences, than they consciously exclude" (1993: 15). However, the difference between the approaches of the "sourcier" and the "ciblistes," although apparent in discussions about translating between related European languages, takes on new significance when the discussions shift to translating between heterogeneous, non-related, language cultures such as that between pre-industrialized and industrialized language cultures. Any theorizing on this form of translation cannot ignore the historical experience of imperialism and the attitudes that obtain thereof on both sides of the imperial divide.

\section{THE IMPERIALIST “CIBLISTE" VERSUS THE, PROTECTIONIST "SOL/RCIER"}

In order to understand the stakes involved in translating the language and literature of the colonized into the language and literature of the colonizer, it is important to 
comprehend why the "aggrieved colonized" might view the "cibliste" approach as imperialist while being somewhat sympathetic to the protectionist approach of the "sourcier."

Antoine Berman defines ethnocentric translation as:

[traduction] qui ramène tout à sa propre culture, à ses normes et valeurs et considère ce qui est situé en dehors de celle-ci - l'Étranger - comme négatif ou tout juste bon à étre annexé. adapté. pour accroître la richesse de cette culture. (1985: 48)

This view of translation led to the "belles infidzles" in the seventeenth and eighteenth centuries in France, a time when translators transformed foreign works as they saw fit.

Berman's definition is an apt description of the attitude - with all its negative attributes - of an avowed "cibliste." The approach of the protectionist "sourcier" (though somewhat ethnocentric as well) aims to counter this inward-looking attitude of the "cibliste." This explains why it is clearly favoured by the "aggrieved colonized" who is particular about making sure that his/her literature is translated into the language of the colonizer with as little distortion as possible. Again, this choice can only be understood in the light of the historical experience of imperialism, or colonialism.

Of course, this does not sit well with the imperialist "cibliste" who would rather "expropriate" or "adapt" the literature of the colonized to the dominant imperial culture. The attitude of the imperialist "cibliste" will fall under Nida's dynamic equivalence approach or Newmark's communicative translation. The protectionist "sourcier" will adopt Nida's formal equivalence approach or Newmark's semantic translation.

\section{IN DEFENCE OF THE PROTECTIONIST "SOURCIER"}

The translation of any non-Western literature into Western languages, e.g., African European language literature, is by definition a heavily culture-dependent and historically bound exercise. Several questions do arise such as how well can the written-based European language culture capture the sociolinguistic and sociocultural realities of a preindustrialized literature which is often steeped in oral tradition? To what extent can one adapt. so to speak. non-Western literature to the sensibilities of a literate Western readership without distorting the literature's very essence? Is it possible to "re-express" this literature in Westem languages without risking the wrath of some "aggrieved colonized" who might consider any form of its adaptation as another attempt at re-colonization? These questions can be better understood in the light of current trends in the area of postcolonial literatures, where some scholars would argue strongly in favour of vernacular language literatures and oppose any attempt to express their literatures in Western languages. In Black Africa, for instance, there is a great divide between proponents of vernacular literature and those who choose to write in Western colonial languages. At the centre of this controversy is not only language but also the question of translation immersed in an imbroglio of ideology, history and tradition. When the Kenyan writer Ngugi wa Thiong 'o (1986), who had written in English for over a decade suddenly vowed never to write in English again, and to write exclusively in Gikuyu his native language, he does not in any way doubt his command of the English language which has been artfully displayed in his many writings. Rather, his decision should be viewed in the light of the perceived difficulties and potential controversy involved in re-expression (or translating) the literature of the "colonized" into the language of the "colonizer." There is a strong resentment among Third World scholars of any perceived attempt at re-colonizing their literatures and cultures. According to Said, this kind of resentment has been triggered by what he refers to as: 
Western views of the Third World which one finds in the work of novelists $[\ldots]$ of theoreticians of imperialism |... J, of travel writers, filmmakers, and polemicists whose specialty is to deliver the non-European world either for analysis and judgement or for satisfying the exotic tastes of European and North American audiences. (1993: .wiii)

Hence, for some Third World scholars, translation should not become the Trojan Horse of Western neo-imperialism. Given the sometimes unflattering role of translation in the colonial history of most Third World peoples, it is not surprising that the movement is heavily weighted in favour of the protectionist "sourciers."

\section{“DISSING" THE IMPERIALIST CIBI.ISTES}

Jean-René Ladmiral (1993) revisits the age-old dichotomy of source-lext oriented translation versus target-text oriented translation, when he discusses what he refers to as the two fundamental ways of translating, namely literalism and semanticism. Literalism refers to Eugene Nida"s "formal equivalence," which Ladmiral describes as "the way of translating (and of theorizing about translation), of the sourciers" (1993: 42). The word sourciers bears an uncanny resemblance to sorciers, a term which might be revealing of Ladmiral's resentment of this approach to translation. Sourcier is quite cleverly rendered in English as sourcerers (also with a striking resemblance to sorcerers, with all the stereotypes conjured up by the term). Semanticism refers to Nida's "dynamic equivalence." which, according to Ladmiral, is "the way of translating (and of theorizing about translation) of the ciblistes" (1993: 42) (or targeteers in English: both English translations are by Newmark). Ladmiral sums up the difference between the two approaches to translation in the following terms:

The sourcerers put the emphasis on the linguistic 'signitier' or 'signifying form' (signifiant) and on the double instance of the source language. essentializing its contingency. as if languages could speak for themselves. On the contrary, the 'largeteers' stress neither the signifying form nor the corresponding units of signification (signifiés) but the global meaning of the author's message, ie., of the discourse to be translated (parole vs language, aceording to de Saussure) that they undertake to render with all proper and specific means of the contingent and 'idiomatic' target-language. (199.3: 42)

Although Ladmiral finally proposes a compromise option referred to as the literary model of translation theory, it is obvious in the above quotation that he has a clear preference for the "targeteer" (rather than the "sourcerer") approach. His disdain for the latter approach (sourcerer) seems to be based on a somewhat narrow point of view which hardly views TS beyond a purely Eurocentric framework. The targeteer's overall objective might seem more logical and more reasonable than the sourcerer's in Ladmiral's terms, but how effective an approach is it when it has to do with expressing the entire gamut of (socio-)linguistic and sociocultural characteristics of a people's literature from a distant, or non-related language culture? For instance, substituting Anglo-Saxon sociocultural realities of Lewis Carroll's Alice in Wonderland for French sociocultural equivalents in a translation aimed at a French audience, as the targeteers would have us do, may be alright for such related language cultures, but is it alright to do the same in translating an African creative piece into French, or English for that matter? By any measure, a targeteer-oriented translation of any piece of African literature into French or English will result in what I would prefer to call "literature about Africa and not African literature" (Bandia 1993: 328). Such "adaptations" can only serve to satisfy a Western audience's craving for exotica.

Hence it seems absurd when Ladmiral takes Berman to task for stating that in translating works of art (i.e., literature and also philosophy) one should translate the 
"signifiant," the "signifier," the signifying form (Ladmiral, op cil). As an avowed targeteer. Ladmiral dismisses Berman's approach as mere literal translation which has "no value at all and therefore should be rejected altogether" (1993: 48). In his view, even works of art are to be translated in the targeteer's manner. Hence, he states:

We have to render 'effects'. the 'effects' of the text: semantic effects and stylistic effects, literary or poetic effects, or even comical effects, etc. We do not have to imitate, to 'ape' the form, the 'signifier'. Translation is not mere linguistic mimicry. (Ladmiral 1993: 48)

Yet. Berman's support for 'sourcerian' translation (to borrow Ladmiral's neologism) is not just about literal translation and all the horrors that it might evoke in the minds of the targeteers. Rather, it is about maintaining the integrity and wholesomeness of a source-text culture as expressed in another target language culture. To achieve a balanced translation of a literary work, meaning and form must be viewed as a whole. In fact, the view of the targeteer that translation is solely a "captation de sens" is highly limited by what Berman describes as "l "adhérence obstinée du sens à sa lettre" (1985: 59). Translation which seeks to capture meaning without regard for the form or style of a work of art is indeed inadequate, and to quote Berman, "la traduction découvre à ses dépens que lettre et sens sont à la fois dissociables et indissociables" (1985: 59). Moreover, every work of art has an untranslatable or unadaptable side to it which is a way of ensuring its "auto-affirmation" (Berman 1985: 60).

Berman's view of the issue provides some basis for understanding why the "aggrieved colonized" would naturally opt for a sourcerian translation of his literature into any Western language, given the historical factors mentioned earlier in this paper. The arrogance and chauvinism (or mere inadvertence) of the targeteers in the performance of this kind of translation is clearly stated in Berman's characterization of ethnocentric translation:

Fondée sur la primauté du sens. elle [la traduction ethnocentrique] considère implicitement ou non sa langue comme un être intouchable et supérieur, que l'acte de traduire ne saurait troubler. Il s'agit d'introduire le sens étranger de telle manière qu'il soit acclimaté, que l'ueuvre étranger apparaisse comme un 'fruit' de la langue propre. (1985: 53)

How presumptuous it is for anyone to try to justify the attempt to "distort" a people's work of art with the overall intent to preserve the host language culture, in the guise of making an alien literature more accessible to the target audience. Translation, of course, is one of the best ways of making alien literatures accessible; however, one should not confuse accessibility with the kind of "sifted" or "watered down" translations produced by targeteers.

For purposes of illustration, let us look at the translation of some culture-specific items of African European language literature. The proverb is a culturally-charged medium of expression for any linguistic community. African proverbs are, of course, no exceptions. Like any other proverbs, the African proverb is a condensed form of expression which carries with it a diversity of factors inherent to the environmental, social and cultural make up of the African world. The world-view expressed in the proverb accounts for its culture specificity. The issue for translators is how to translate the African proverb into a Westem language and all the while maintaining the proverb's culture specificity. As pointed out by Snell-Hornby:

The essential problem posed by metaphor in translation is that different cultures, hence different languages, conceptualize and create symbols in varying ways, and therefore the sense of the metaphor is frequently culture-specific. (1988: 57) 
The following are two African proverbs each followed by a sourcerian translation and a targeteerian translation:

(1) "Whenever you see a toad jumping in broad daylight, then know that something is after its life" (Achehe 1958: 143)

Sourcerian translation:

"Toutes les fois que tu verras un crapaud bondir en plein jour, alors sache que quelque chose menace sa vie" (Ligny 1966: 246).

Targeteerian translation:

"Il n'y a pas de fumée sans feu".

(2) "An old woman is always uneasy when dry bones are mentioned in a proverb" (Achebe 1958: 15$)$

Sourcerian translation:

"Une vieille femme est toujours gênée quand on parle d'os desséchés dans un proverbe" (Ligny 1966: 30).

Targeteerian translation:

"Il ne faut pas parler de corde dans la maison d"un pendu" (Rat 19.57: 121).

In each example, the overall meaning of the sourcerian and targeteerian translations is the same, i.e., the two translations are about a smilar universal truth, or fact. However, the proverbs are not the same. The sourcerian translation is indeed the closest you can get to an African proverb, whereas the targeteerian translation is basically French, and has nothing African about it. If only meaning (understood beyond its functional-pragmatic and restrictive sense) is the overriding factor in a translation, as the targetecrs would have us believe, then African proverbs and other culture-specific items being translated into French would simply be replaced with French equivalents. lest there be an unwarranted "pollution" of the genius of the French language and culture. Targeteers would, of course, dismiss the sourcerian translations of these proverbs as "mere linguistic mimicry." Yet, as Berman explains, literal translation is not necessarily "mot-à-mot servile... ni calque, ni reproduction, mais attention portée au jeu des signifiants" (1985: 36). The targeteerian translations suggested here are good examples of ethnocentric translation which, according to Berman, result in "...souffrance... celle du texte traduit. Celle du sens privé de sa lettre" (1985: 59). The targeteers seem to have quite a simplistic view of the concept of equivalence in translation. One would like to think that looking for equivalents is not simply looking for an invariant meaning, an ideal meaning expressed in different proverbs from one language to another. If anything. the targeteerian approach says a lot more about linguistic attitudes than it does about translation. Berman lashes out against this linguistic "xenophobia" of the targeteer when he states:

C"est refuser d'introduire dans la langue traduisante l'ctrangete' du proverbe original, $[\ldots \mid$ $c^{\prime}$ est refuser de faire de la langue traduisante 'l'auberge du lointain'. c'est, pour nous, franciser : vieille tradition. Pour le traducteur formé a cetle école, la traduction est une transmission de sens qui. en même temps. est tenue de rendre ce sens plus clair. de le ne'flover des

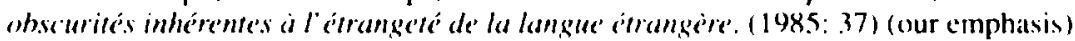

The sourcerian approach so far seems to be the most reliable way of preserving the originality of the proverbs. 


\section{IS THERE A MIDDLE GROUND?}

Current debates about the traditional dichotomy - source-text oriented versus target-text oriented translation - have become extremely aggressive, with less and less chances for compromise. The tensions have increased as professional translators question and even ridicule the works of translation theorists, at times dismissing them as mere art for art's sake. If these trends continue, the chances of finding a comprehensive translation theory will remain bleak. The polemic between the "sourciers" and the "ciblistes" certainly transcends the issue of finding a scientific method to account for an objective activity. As clearly stated by Ladmiral, "Iranslation is a 'setting'. a configuration revealing something of our deep relation to the written word (l'écrit). It is as if the source-text perhaps every source-text - was seen as a sacred text but, of course, in an unconscious way" (1993: 46). The sourciers as well as the ciblistes have an almost religious attachment to their respective views, what Ladmiral describes as "two possible translation theologies in opposition: the theology of the Letter and the theology of the Spirit" (1993: 46). Some attempts, though so far unsuccessful, have been made to reconcile these opposing views. On his part. Ladmiral has suggested what he calls a philosophical model of translation for translation theory. This in tum is rooted in a literary model of translation theory which will develop the aesthetics of translation and bring about "a possible systematization of the 'Art of translating', of a theory of literary genres and its implications for translations" (1993: 42). In such an approach, even non-literary texts can be analyzed from a literary standpoint as "every translation has a minimal literary dimension as a written text" (1993: 43). The problem with Ladmiral's suggestion is that it is still too close for comfort to his obvious cibliste orientation.

Nouss (1993) proposes the inclusion of a hermeneutical approach to the process of translation as a healthy compromise. The hermeneutical approach would give priority to the process of comprehension and interpretation which, in his view, should take precedence over any other reflection on language and discourse. It is believed that this approach can provide a forum to account for the apparent strangeness of a source text. In this regard, Nouss agrees with Berman (1985) on placing emphasis on the creative dimension of language thus accounting for the subjective and historical factors which must be conveyed in an adequate translation. Citing Gadamer, Nouss points to a "true hermeneutics of translation" as that which results in a merging of horizons, that is, the merging of "the world to be translated and the world of the translator" (1993: 60). Under such circumstances, the translator is never limited to any particular horizon. he/she is neither a sourcier nor a cibliste.

These compromise views echo those put forth by Berman when he points out that it is inappropriate to view translation either exclusively as "captation de sens" or "Iransformation littéraire" (1985: 58). A similar position is taken by Newmark (1981) when he asserts that a translation is neither completely semantic nor completely communicative.

We can only take solace in these attempts to broker peace between the sourcicr and the cibliste camps, as such a move has the potential to provide the means by which distant, or alien, literatures and cultures will be given their due place in TS. Non-European literatures and cultures can contribute a great deal to our understanding of the translation process. Therefore, the debate about the search for a comprehensive translation theory has to transcend its current Eurocentric confines if we hope to find a truly universal theory.

\section{REFERENCES}

ACHEBE. C. (1958): Things Fall Apart. London. Heinemann.

ACHEBE. C. (1966): Le monde s' effondre. Trans. by M. Ligny. Paris. Présence Africaine 
BANDIA. P. (199.3): Sociolinguistic and Sociocultural Aspects of Transiation: A Cross-Cultural Study in an Africun Context, Ph.D. Dissertation. Université de Montréal.

BERMAN. A. (1985): Les Tours de Babel: essais sur la traduction, Mauvezin. Trans-Europ Repress.

GAMBIER. Y. and J. TOMMOLA (Eds.) (1993): Translation and Knowiledge, SSOTT IV. University of Turku. Centre for Translation and Interpreting.

LADMIRAL, J.R. (1993): "Towards a Philosophy of Translation". Y. (iambier and J. Tommola (Eds.). Translation and Knowledge, pp 41-52.

NEWMARK, P. (1981): Approaches o' Translation, Oxford, Pergamon Press.

NGUGi, Wa Thiongo'o (1986): Decolomising the Mind: The Politics of Language in African Laterature. London, James Curry.

NIDA, E. and C. TABER (1974): The Theory and Practice of Transiation, Leiden. E. J. Brill.

NOUSS, A. (149.3): "Translation: An or Science"? A Hermeneutical Reading". Y. Gambier and J. Tommola (Eds.). Translation and Knowledge, pp. 53-66.

RAT, M. (1957): Dictionnaire de's In'urions françaises, Paris, Larousse.

SAID, E. (1993): ('ulture and Impertalism, New York. Knopf.

SNELL-HORNBY. S. (1988): Translation Studies: An Integrated Approach. Amsterdam/Philadelphia. John Benjamins. 